\title{
Prescription of red cell concentrates by emergency physicians
}

\author{
(D) João Carlos Pina Faria ${ }^{\mathbf{1 , 2 , 3}}$ \\ (iD) Bianca Cansian ${ }^{4}$ \\ Déric Edmur Camargo Arruda $a^{3,5}$ \\ (iD) Camila Augusta Victorino $0^{\mathbf{1 , 6}}$ \\ (iD) Alexandre Szulman 7,8
}

\begin{abstract}
1. Mestre em Ciências da Saúde pela Faculdade de Medicina do ABC, Santo André, SP, Brasil 2. Médico preceptor do Centro Universitário Saúde ABC (Faculdade de Medicina do ABC), Santo André, SP, Brasil 3. Docente do curso de Medicina da Universidade Nove de Julho, São Paulo, SP, Brasil

4. Discente do curso de Medicina da Universidade Nove de Julho, São Paulo, SP, Brasil 5. Mestre em Ciências da Reabilitação pela Universidade Nove de Julho, São Paulo, SP, Brasil 6. Médica docente do curso de Medicina da Universidade Nove de Julho. São Paulo, SP, Brasil 7. Médico hematologista da Colsan (Associação Beneficente de Coleta de Sangue), São Paulo, SP, Brasil 8. Responsável técnico da agência transfusional do Hospital e Pronto-Socorro Central de São Bernardo do Campo, São Bernardo do Campo, SP, Brasil
\end{abstract}

http://dx.doi.org/10.1590/1806-9282.66.4.466

\section{SUMMARY}

OBJECTIVE: To evaluate the adequacy of the prescription of red cell concentrates by emergency physicians.

METHODS: A cross-sectional study based on the survey of transfusion requests records completed by emergency physicians, from May/2018 to April/2019, in an emergency hospital. Adequacy in the indication, volume, and subtype (filtered, irradiated, and washed) of prescribed erythrocytes were evaluated. To compare the qualitative data, we used the $\chi 2$ test. The significance level adopted was $5 \%$. RESULTS: One thousand and twenty-two transfusions were evaluated. The indication, volume, and subtypes were correct in $72.7 \%, 45.9 \%$, and $81.6 \%$ respectively. Transfusion in symptomatic patients presented superior adequacy when compared to asymptomatic individuals with significant statistical difference (indication: $79,6 \%$ vs $67.2 \%, p<0.001$; Volume: $63.5 \%$ vs $37.7 \%, p<0.001$; subtype: $85.3 \%$ vs $78.7 \%$, $p$ 0.006). Among clinical situations, there were more errors in sepsis (39.7\%) and pneumonia (36.3\%). More than half of the prescriptions presented excessive volume, raising the risk of circulatory overload, observing that the mean age was 60.6 years. The specific analysis of the prescribed subtypes showed adequacy of $17.9 \%$ in the filtered, $1.7 \%$ in the irradiated, and none in the washed. Thirty transfusions should have been filtered, but the prescriber did not request the subtype.

CONCLUSION: One hypothesis for the observed inaccuracies is inadequate medical training on the subject, both in undergraduate and medical residency, associated with a lack of continuing education on transfusion protocols. The transfusion Committee received the results of this study with a proposal for continuing education measures on transfusion hemotherapy.

KEYWORDS: Erythrocyte transfusion. Blood transfusion. Emergency treatment. Prescriptions. Transfusion medicine.

\section{INTRODUCTION}

Richard Lower conducted, in 1665, in England, the first blood transfusion between animals ${ }^{1}$. This procedure, then, was tested in humans in the following decades and is currently one of the most used therapies in the world ${ }^{2}$.
The transfusion of red cell concentrate (RCC) increased survival in different clinical situations and surgical procedures. However, it can be the cause of increased mortality when prescribed without need ${ }^{3}$.

Recent studies show that a restrictive strategy

DATE OF SUBMISSION: 12-Nov-2019

DATE OF ACCEPTANCE: 24-Nov-2019

CORRESPONDING AUTHOR: João Carlos Pina Faria

Centro Universitário Saúde ABC (Faculdade de Medicina do ABC), Avenida Lauro Gomes, 2000, Vila Sacadura Cabral - Santo André / SP -

Brasil. CEP 09060-870 - Telefone: + 55 (11) 4993-5400.

E-mail: jocapf79@gmail.com 
(indicating RCC with lower values of hemoglobin) reduces mortality in severe patients ${ }^{4.5}$. Transfusion protocols indicate the red blood cell transfusion for patients with a hemoglobin count of less than $7 \mathrm{~g} / \mathrm{dL}$ in most situations ${ }^{6}$. However, many physicians are unaware of the transfusion protocols or are resistant to apply the restrictive strategy, increasing the risks to patients and the number of RCCs prescribed ${ }^{7-9}$.

Various transfusion reactions can occur, some potentially lethal, such as anaphylaxis, circulatory overload, and TRALI (transfusion-related acute lung injury) ${ }^{10.11}$.

RCC transfusion is an important part of therapy in various clinical situations, especially in urgency and emergency scenarios ${ }^{12-14}$. Having knowledge of current protocols is essential for emergency physicians.

The objective of this study is to evaluate the adequacy of RCC prescriptions by physicians of an urgency and emergency hospital.

\section{METHODS}

We conducted a cross-sectional study based on a survey of request forms for a hemotherapy procedure. We included patients aged over 13 years treated in the emergency room of the medical clinic of the Central Hospital and Emergency Center of São Bernardo do Campo (HPSC), SP, from May 2018 to April 2019. This is a public municipal hospital that receives urgent and emergency cases and that features a transfusion agency. Forms with incomplete data were excluded from the analysis.

The adequacy of the RCC prescription was based in three distinct forms of analysis: indication of transfusion based on the value of hemoglobin $(\mathrm{Hb})$, the prescribed volume, and choice for the correct subtype (filtered, irradiated, washed). To assess the adequacy of the indication, the prescribed volume, and the choice of RCC subtypes, we used the recommendations by the Brazilian Ministry of Health from $2015^{15}$. To analyze the transfusions indicated for sepsis patients, we used the international guidelines for sepsis management ${ }^{16}$.

We collected data such as age, gender, indication, pretransfusion hemoglobin, prescribed volume, choice of RCC subtype, and previous diseases. The data were entered into an Excel (Microsoft) spreadsheet and analyzed using the Statistical Package for Social Science (SPSS), version 24.0. The qualitative variables were presented in the form of an absolute number and percentage. For the comparison of the qualitative data, we used the $\chi 2$ test. The significance level adopted was $5 \%$.

This study was approved by the Research Ethics Committee of the Faculty of Medicine of ABC (Decision No.: 3.286.784), CAAE 11199319.2.0000.0082.

\section{RESULTS}

A total of 1,044 RCC transfusions were performed during the study period, of which 22 (2.1\%) were excluded due to incomplete data. Males received $55.1 \%$ of the transfusions (Table 1). The mean age was 60.6 years (minimum of 14 , and a maximum of 100 years).

Most transfusions (55.5\%) were prescribed based on a laboratory indication (anemia) in asymptomatic patients. The most prevalent clinical indications were: enterorrhagia (40.9\%), hemodynamic decompensation (13\%), sepsis (12.8\%), and lower gastrointestinal bleeding (9.7\%) (Table 1). Indications were made with less than $7 \mathrm{~g} / \mathrm{dL}$ in $69.3 \%$ of transfusions. Laboratory criteria had an average $\mathrm{Hb}$ of $6.6 \mathrm{~g} / \mathrm{dL}$, while the transfusions based on clinical criteria had an average $\mathrm{Hb}$ of $6.3 \mathrm{~g} / \mathrm{dL}$. The prescriptions were as follows: one pack of RCC for 313 patients, two packs for 588 , three packs for 113, and four packs for eight. The average number of packs prescribed based on laboratory indication was 1.8 and, based on clinical indication, 1.9 (Table 1).

A total of 185 specific subtypes of RCC were requested. In 45 transfusions, two or three subtypes were prescribed simultaneously. The subtype most frequently requested was irradiated RCC (119), followed by filtered RCC (56), and washed RCC (10) (Table 1).

The indication for transfusion was correct in $72.7 \%$ of the cases evaluated. When performed based on laboratory criteria, the adequacy was $67.2 \%$, and when based on clinical criteria, $76.9 \%$ (Table 2). In relation to the clinical reason, sepsis presented adequacy of $60.3 \%$, and pneumonia $63.7 \%$. The other reasons had adequacy over $70 \%$. Adequacy was significantly higher in the group who received transfusions based on clinical criteria, compared to the group based on laboratory indication, with $\mathrm{p}<0.001$ (Figure 1).

Transfusions performed with $\mathrm{Hb}<7 \mathrm{~g} / \mathrm{dL}, 7$ to $10 \mathrm{~g} /$ $\mathrm{dL}$, and $>10 \mathrm{~g} / \mathrm{dL}$ were correct in $100 \%, 11.2 \%$, and $0 \%$ of cases, respectively (Table 2).

The volume (number of packs) was correct in $45.9 \%$ of the transfusions. When one RCC was requested, adequacy was $99 \%$, and when the number was two, it was $27 \%$. All requests for over two RCCs were 
TABLE 1. GENERAL CHARACTERISTICS OF

TRANSFUSIONS PERFORMED

\begin{tabular}{|c|c|c|c|}
\hline \multicolumn{2}{|l|}{ Variable } & $N$ & $\%$ \\
\hline Gender & Male & 563 & 55.1 \\
\hline$(n=1,022)$ & Female & 459 & 44.9 \\
\hline Age (years) & $|14|---20$ & 21 & 2.1 \\
\hline \multirow[t]{4}{*}{$(n=1,022)$} & $20 \mid---40$ & 123 & 12.0 \\
\hline & $40 \mid---60$ & 323 & 31.6 \\
\hline & $60 \mid---80$ & 428 & 41.9 \\
\hline & $80 \mid---100$ & 127 & 12.4 \\
\hline Clinical condition & Enterorrhagia & 186 & 40.9 \\
\hline \multirow[t]{9}{*}{$(n=455)$} & Hemodynamic decompensation & 59 & 13.0 \\
\hline & Sepsis & 58 & 12.8 \\
\hline & Lower gastrointestinal bleeding & 44 & 9.7 \\
\hline & Weaknesses & 27 & 5.9 \\
\hline & Sickle cell disease & 16 & 3.5 \\
\hline & Hematuria & 15 & 3.3 \\
\hline & Acute respiratory failure & 12 & 2.6 \\
\hline & Pneumonia & 11 & 2.4 \\
\hline & Others & 27 & 5.9 \\
\hline Reason & Laboratory (asymptomatic) & 567 & 55.5 \\
\hline$(n=1,022)$ & Clinical (symptomatic) & 455 & 44.5 \\
\hline $\begin{array}{l}\text { Pretransfusion } \\
\mathrm{Hb}\end{array}$ & $<7 \mathrm{~g} / \mathrm{dL}$ & 708 & 69.3 \\
\hline \multirow[t]{2}{*}{$(n=1,022)$} & 7 to $10 \mathrm{~g} / \mathrm{dL}$ & 313 & 30.6 \\
\hline & $>10 \mathrm{~g} / \mathrm{dL}$ & 1 & 0.1 \\
\hline $\begin{array}{l}\text { Prescribed } \\
\text { volume }\end{array}$ & $1 \mathrm{CH}$ & 313 & 30.6 \\
\hline \multirow[t]{3}{*}{$(n=1,022)$} & $2 \mathrm{CH}$ & 588 & 57.6 \\
\hline & $3 \mathrm{CH}$ & 113 & 11.0 \\
\hline & $4 \mathrm{CH}$ & 8 & 0.8 \\
\hline RCC subtype & Filtered & 56 & 30.3 \\
\hline \multirow[t]{2}{*}{$(n=185)$} & Irradiated & 119 & 64.3 \\
\hline & Washed & 10 & 5.4 \\
\hline
\end{tabular}

incorrect (Table 2). The adequacy in the volume prescription based on laboratory criteria was $31.7 \%$, and based on clinical criteria, $63.5 \%$, with a statistically significant difference $(\mathrm{p}<0.001)$ (Figure 1).

In 188 transfusions $(18.4 \%)$ there was an error in the prescription of RCC subtype (unnecessarily requested or not requested when indicated). In 158 prescriptions, one or more subtypes were requested with no need, totaling 173 subtypes (Table 1). On the other hand, in 30 transfusions the filtered subtype was not prescribed when there was an indication. Irradiated RCC was prescribed in 119 blood transfusions,
TABLE 2. ADEQUACY OF THE RED CELL CONCENTRATE TRANSFUSION

\begin{tabular}{|c|c|c|c|c|}
\hline \multicolumn{2}{|l|}{ Variable } & $\begin{array}{l}\text { Total } \\
(\mathrm{N})\end{array}$ & $\begin{array}{l}\text { Correct } \\
(\mathrm{N})\end{array}$ & $\begin{array}{l}\text { Correct } \\
(\%)\end{array}$ \\
\hline Indicated & Laboratory & 567 & 381 & 67.2 \\
\hline$(n=1,022)$ & Clinic & 455 & 362 & 79.6 \\
\hline Clinical condition & Enterorrhagia & 186 & 131 & 70.4 \\
\hline \multirow[t]{9}{*}{$(n=455)$} & $\begin{array}{l}\text { Hemodynamic decom- } \\
\text { pensation }\end{array}$ & 59 & 57 & 96.6 \\
\hline & Sepsis & 58 & 35 & 60.3 \\
\hline & $\begin{array}{l}\text { Lower gastrointestinal } \\
\text { bleeding }\end{array}$ & 44 & 31 & 70.5 \\
\hline & Weaknesses & 27 & 27 & 100 \\
\hline & Sickle cell disease & 16 & 15 & 93.8 \\
\hline & Hematuria & 15 & 13 & 86.7 \\
\hline & Acute respiratory failure & 12 & 11 & 91.7 \\
\hline & Pneumonia & 11 & 7 & 63.7 \\
\hline & Others & 27 & 23 & 85.1 \\
\hline $\begin{array}{l}\text { Pretransfusion } \\
\mathrm{Hb}\end{array}$ & $<7 \mathrm{~g} / \mathrm{dL}$ & 708 & 708 & 100 \\
\hline \multirow[t]{2}{*}{$(n=1,022)$} & 7 to $10 \mathrm{~g} / \mathrm{dL}$ & 313 & 35 & 11.2 \\
\hline & $>10 \mathrm{~g} / \mathrm{dL}$ & 1 & 0 & 0 \\
\hline $\begin{array}{l}\text { Prescribed } \\
\text { volume }\end{array}$ & $1 \mathrm{CH}$ & 313 & 310 & 99 \\
\hline \multirow[t]{3}{*}{$(n=1,022)$} & $2 \mathrm{CH}$ & 588 & 159 & 27 \\
\hline & $3 \mathrm{CH}$ & 113 & 0 & 0 \\
\hline & $4 \mathrm{CH}$ & 8 & 0 & 0 \\
\hline RCC subtype & Filtered & 56 & 10 & 17.9 \\
\hline \multirow[t]{2}{*}{$(n=185)$} & Irradiated & 119 & 2 & 1.7 \\
\hline & Washed & 10 & 0 & 0 \\
\hline
\end{tabular}

of which 117 (98.3\%) had no need for it. Filtered RCC was prescribed in 56 transfusions and was incorrect in $46(82.1 \%)$ of them. Washed RCC was prescribed ten times, all inappropriately (Table 2). The adequacy of the request for the RCC subtypes in transfusions prescribed based on laboratory and clinical indication was $78.7 \%$ and $85.3 \%$, respectively (p 0.006) (Figure 1).

\section{DISCUSSION}

A greater number of blood transfusions were performed in asymptomatic patients, situations in which physicians had time to discuss the clinical case with other colleagues or with the hematologist of the hospital transfusion agency. When patients were symptomatic, the main cause was enterorrhagia.

Almost 70\% of transfusions occurred in patients with $\mathrm{Hb}$ less than $7 \mathrm{~g} / \mathrm{dL}$, a trigger that indeed indicates 
the need for transfusion in most clinical situations ${ }^{15}$. Patients in hospitals that follow a restrictive transfusion trigger (perform transfusions in patients with $\mathrm{Hb}$ less than $7 \mathrm{~g} / \mathrm{dL}$ ) receive fewer transfusions than those in hospitals that adopt liberal transfusion strategies ${ }^{\mathbf{1 7}}$. Another benefit of the restrictive strategy is the reduction of transfusion reactions in severe patients ${ }^{\mathbf{1 8}}$. All transfusions performed with $\mathrm{Hb}$ below $7 \mathrm{~g} / \mathrm{dL}$ were correct; however, only $11.2 \%$ of those performed with $\mathrm{Hb}$ from 7 to $10 \mathrm{~g} / \mathrm{dL}$ were appropriate.

The adequacy in the indication was significantly higher in symptomatic patients. There were more errors in cases of sepsis, for which the current guideline recommends transfusion when $\mathrm{Hb}$ levels are below $7 \mathrm{~g} / \mathrm{dL}^{16}$. Patients with pneumonia without respiratory insufficiency or mechanical ventilation received unnecessary transfusions in almost $40 \%$ of cases.

There was excessive volume in $54.1 \%$ of prescriptions. All requests for over 2 RCCs were incorrect. The circulatory overload related to a high volume of blood transfusion is one of the most frequent transfusion reactions and presents high mortality ${ }^{19}$. In our study, we found that $54.3 \%$ of the patients were over 60 years old, increasing, even more, the risk of transfusion reaction. An American cohort study also observed a greater number of transfusions in elderly patients treated in emergency rooms ${ }^{20}$.
Only $6.5 \%$ of the specific subtypes prescribed were adequate. It was also observed that in 30 transfusions filtered RCC was indicated but it was not prescribed. All these situations occurred in patients with hemoglobinopathies (27 with sickle cell disease and three with thalassemia major). Filtered RCC is indicated especially in polytransfused patients, such as those with hemoglobinopathies, to prevent febrile non-hemolytic reaction ${ }^{15}$. The prescription of subtypes without need results in increased treatment costs ${ }^{21}$. In some situations, it can increase the wait time for a severe patient due to the preparation time of the subtype ${ }^{21}$. This factor results in an increased risk of death if the transfusion is indicated in emergencies. The washed subtype presents a further complication when unnecessarily requested: it reduces in up to $20 \%$ the number of red blood cells, decreasing the transfusion yield ${ }^{22}$.

When comparing the group that received transfusions based on clinical criteria (symptomatic) with the group that received it based on laboratory criteria (asymptomatic), we observed that the indication, the calculation for volume, and the choice of subtypes presented higher adequacy in the symptomatic group, with a statistically significant difference in the three analyses.

A hypothesis that justifies the inaccuracies observed is the inadequate medical training on the

FIGURE 1. ADEQUACY OF TRANSFUSION COMPARING LABORATORY AND CLINICAL INDICATIONS

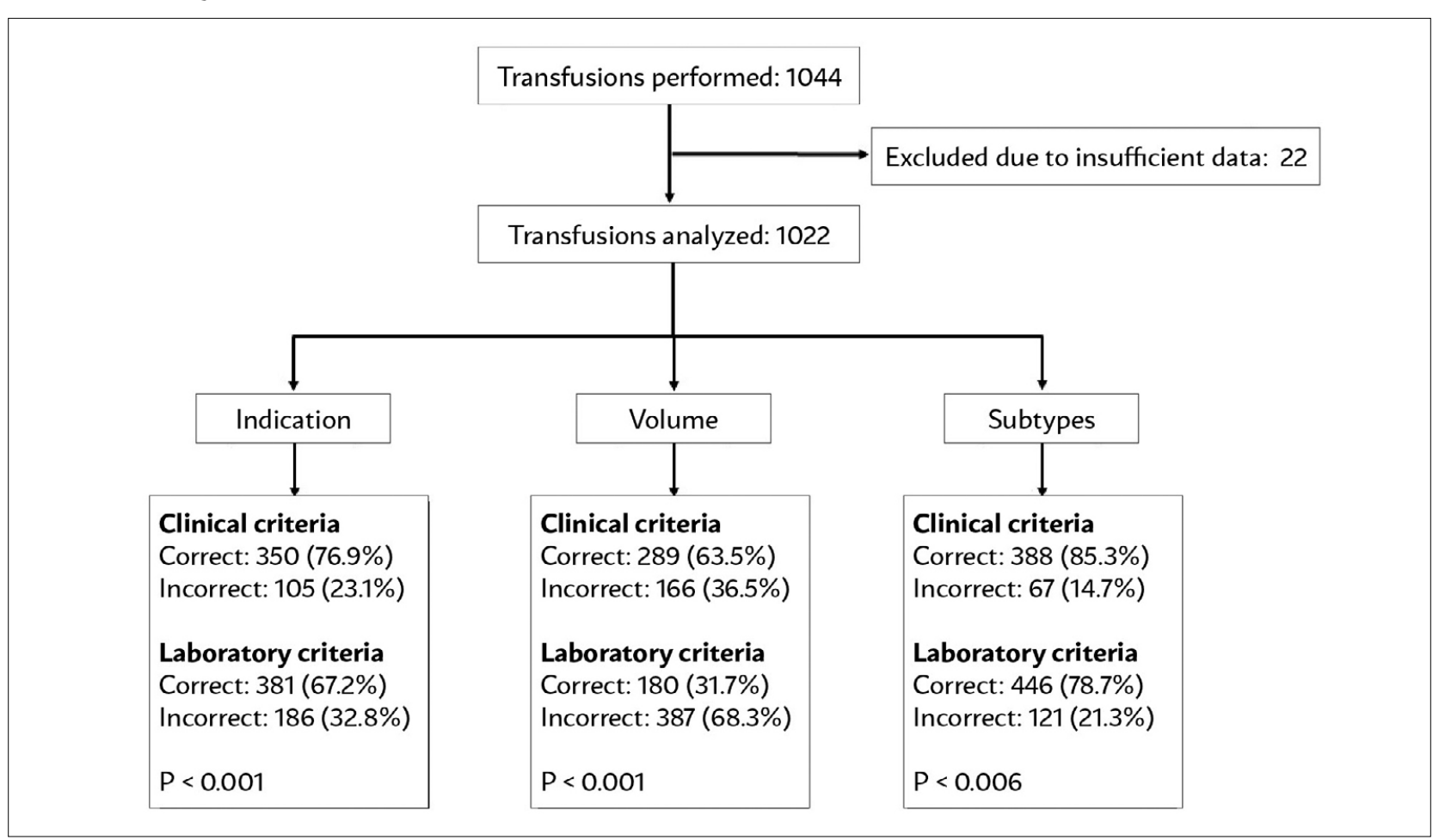


subject, both in undergraduate programs and in medical residency. Associated with this, is the lack of continuing education of emergency physicians on transfusion protocols. Since the need to improve the indications for transfusion of red cell concentrate was observed, the hospital transfusion committee received the results of this study with the proposal for measures of continuing education on transfusion hemotherapy. Continuing education is proven to improve the knowledge of the physicians on hemotherapy ${ }^{23.24}$. The lack of knowledge of transfusion protocols increases the risks to patients, making training necessary ${ }^{25}$.

The strengths of this study were the number of transfusions evaluated, the analysis of the requests made specifically by emergency physicians of the medical clinic, a small percentage of loss (2.1\%), and the availability of an official guide on the indications for transfusion by the Brazilian Ministry of Health, in addition to international guidelines for comparison of the results.
As to the limitations, one can cite the retrospective design of the study and the absence of details on the clinical history in the request form for the hemotherapy procedure.

\section{CONCLUSION}

Transfusions in asymptomatic patients require caution. The protocols for transfusion in sepsis and in patients with respiratory diseases without respiratory failure should be discussed. In relation to the excessive volume of packs prescribed, only in severe cases, such as hemorrhagic hypovolemic shock, a greater number of packs must be requested. The knowledge of subtypes must also be emphasized, because of the lack of prescription when there is an indication increases transfusion risks, while unnecessary prescriptions also present complications. In case of doubt, the issue should be discussed with the hemotherapist of the transfusion agency.

\section{RESUMO}

OBJETIVO: Avaliar a adequação da prescrição de concentrados de hemácias por médicos emergencistas.

MÉTODOs: Estudo transversal por levantamento de fichas de requisição de transfusões preenchidas por médicos emergencistas, no período de maio de 2018 a abril de 2019, em um hospital de emergências. Foram avaliadas as adequações na indicação, volume e subtipo (filtradas, irradiadas e lavadas) de hemácias prescritas. Para comparação dos dados qualitativos, utilizamos o teste de $\chi 2$. 0 nível de significância adotado foi de 5\%.

RESULTAdOS: Foram avaliadas 1.022 transfusões. A indicação, o volume e os subtipos estavam corretos em 72,7\%, 45,9\% e 81,6\%, respectivamente. A transfusão prescrita em pacientes sintomáticos apresentou adequação superior quando comparada aos assintomáticos, com diferença estatística significativa (indicação: 79,6\% vs 67,2\% - p<0,001; volume: 63,5\% vs 31,7\% - p<0,001; subtipo: $85,3 \%$ vs 78,7\% - p 0,006). Entre as situações clínicas, ocorreram mais erros na sepse (39,7\%) e pneumonia (36,3\%). Mais da metade das prescrições apresentavam volume excessivo, elevando o risco de sobrecarga circulatória, observando-se que a média da idade foi 60,6 anos. A análise específica dos subtipos prescritos apresentou adequação de 17,9\% nas filtradas, 1,7\% nas irradiadas e nenhuma das lavadas. Trinta transfusões deveriam ter sido filtradas, porém o prescritor não solicitou o subtipo.

CONCLUSÃo: Uma hipótese para as incorreções observadas é a formação médica inadequada sobre o assunto, tanto na graduação como na residência médica, associada à falta de atualização nos protocolos transfusionais. O comitê transfusional recebeu os resultados deste estudo com proposta de medidas de educação permanente sobre hemoterapia transfusional.

PALAVRAS-CHAVE: Transfusão de eritrócitos. Transfusão de sangue. Tratamento de emergência. Prescrições. Medicina transfusional.

\section{REFERENCES}

1. Freedman J. Transfusion: whence and why. Transf Apher Sci. 2014;50(1):5-9.

2. Szczepiorkowski ZM, Dunbar NM. Transfusion guidelines: when to transfuse. Hematology Am Soc Hematol Educ Program. 2013;2013:638-44.

3. Sutton DH, Raines DA. The risks associated with red blood cell transfusion. Crit Care Nurs Clin North Am. 2017;29(3):305-14.

4. Chong MA, Krishnan R, Cheng D, Martin J. Should transfusion trigger thresholds differ for critical care versus perioperative patients? A meta-analysis of randomized trials. Crit Care Med. 2018;46(2):252-63.

5. Rahimi-Levene N, Ziv-Baran T, Peer V, Golik A, Kornberg A, Zeidenstein R, et al. Hemoglobin transfusion trigger in an internal medicine department: a "real world" six year experience. PLoS One. 2018;13(3):e0193873.

6. Connor JP, Raife T, Medow JE. Outcomes of red blood cell transfusions prescribed in organ donors by the Digital Intern, an electronic decision support algorithm. Transfusion. 2018;58(2):366-71.
7. Alamri AA, Alnefaie MN, Saeedi AT, Hariri AF, Altaf A, Aljiffry MM. Transfusion practices among general surgeons at a tertiary care center: a survey based study. Med Arch. 2018;72(6):418-24.

8. Tavousi SH, Ahmadabadi A, Sedaghat A, Khadem-Rezaiyan M, Yaghoubi Moghaddamd Z, Behrouzian MJ, et al. Blood transfusion in burn patients: triggers of transfusion in a referral burn center in Iran. Transfus Clin Biol. 2018;25(1):58-62.

9. Curinga G, Jain A, Feldman M, Prosciak M, Phillips B, Milner S, et al. Red blood cell transfusion following burn. Burns. 2011;37(5):742-52.

10. Savage WJ. Transfusion medicine and hemostasis: allergic transfusion reactions. $3^{\text {rd }}$ ed. Amsterdã: Elsevier Science; 2019. p.389-92.

11. Janssen MP, van Tilborgh AJW, de Vooght KMK, Bokhorst AG, Wiersum-Osselton JC. Direct costs of transfusion reactions: an expert judgement approach. Vox Sang. 2018;113(2):143-51. 
12. Martucci G, Grasselli G, Tanaka K, Tuzzolino F, Panarello G, Schmidt M, et al. Hemoglobin trigger and approach to red blood cell transfusions during veno-venous extracorporeal membrane oxygenation: the international TRAIN-ECMO survey. Perfusion. 2019;34(1 suppl):39-48.

13. Hirano Y, Miyoshi Y, Kondo Y, Okamoto K, Tanaka H. Liberal versus restrictive red blood cell transfusion strategy in sepsis or septic shock: a systematic review and meta-analysis of randomized trials. Crit Care. 2019;23(1):262.

14. Moller A, Nielsen HB, Wetterslev J, Pedersen OB, Hellemann D, Winkel P, et al. Low vs. high hemoglobin trigger for transfusion in vascular surgery: a randomized clinical feasibility trial. Blood. 2019;133(25):2639-50.

15. Brasil. Ministério da Saúde. Guia para o uso de hemocomponentes. $2^{a}$ ed. Brasília: Ministério da Saúde; 2015. [cited 2019 july 29]. Available from: http://bvsms.saude.gov.br/bvs/publicacoes/guia_uso_hemocomponentes_2ed.pdf

16. Rhodes A, Evans LE, Alhazzani W, Levy MM, Antonelli M, Ferrer R, et al. Surviving sepsis campaign: international guidelines for management of sepsis and septic shock: 2016. Intensive Care Med. 2017;43(3):304-77.

17. Mazer CD, Whitlock RP, Fergusson DA, Belley-Cote E, Connolly K, Khanykin $B$, et al; TRICS Investigators and Perioperative Anesthesia Clinical Trials Group. Six-month outcomes after restrictive or liberal transfusion for cardiac surgery. N Engl J Med. 2018;379(13):1224-33.

18. Endo A, Shiraishi A, Fushimi K, Murata K, Otomo Y. Outcomes of patients receiving a massive transfusion for major trauma. $\mathrm{Br}$ | Surg. 2018;105(11):1426-34

19. Hébert PC, Wells G, Blajchman MA, Marshall J, Martin C, Pagliarello G, et al. A multicenter, randomized, controlled clinical trial of transfusion requirements in critical care. Transfusion Requirements in Critical Care Investigators, Canadian Critical Care Trials Group. N Engl J Med. 1999;340(6):409-17.

20. Loftus TJ, Brakenridge SC, Murphy TW, Nguyen LL, Moore FA, Efron PA, et al. Anemia and blood transfusion in elderly trauma patients. J Surg Res. 2018;229:288-93.

21. Hasler S, Kleeman A, Abrams R, Kim J, Gupta M, Krause MK, et al. Patient safety intervention to reduce unnecessary red blood cell utilization. Am J Manag Care. 2016;22(4):295-300.

22. Fung MK, Grossman BJ, Hillyer CD, Westhoff CM. Technical manual. $19^{a}$ ed. Maryland: Editora AABB; 2017.

23. Champion C, Saidenberg E, Lampron J, Pugh D. Blood transfusion knowledge of surgical residents: is an educational intervention effective? Transfusion. 2017;57(4):965-70.

24. Graham JE, Narayan S, Pendry K. Improving transfusion education for junior doctors; exploring UK experiences. Transfus Med. 2017;27(2):96-104.

25. Ben Romdhane AR, Ben Ayoub W, Gouider E. Evaluation of non-compliance of transfusion requests of packed red blood cells. Tunis Med. 2015;93(6):361-4 